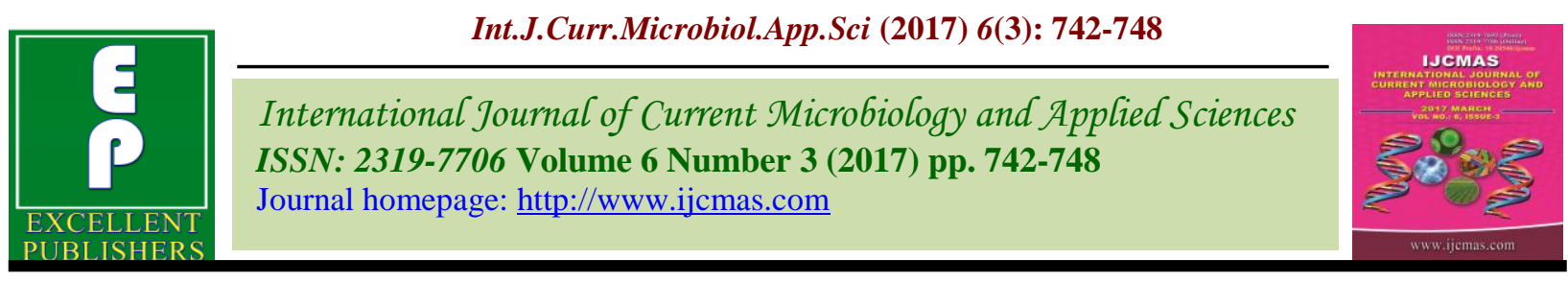

Original Research Article

https://doi.org/10.20546/ijcmas.2017.603.086

\title{
Comparative Assessment between Serological and Molecular Diagnosis for Patients Groups with Hepatitis B Virus
}

\author{
Intisar Jebbar Radii and Asmaa Mohammed Saud*
}

University of Baghdad / College of Science / Biotechnology Department, Iraq

*Corresponding author:

\section{A B S T R A C T}

This study attempted to determine the prevalence of HBV infection and comparative assessment between serological and molecular diagnoses among 75 samples divided into three groups as treated, untreated and control groups from different cities in Wasit Province, Iraq, during the period from March 2016 to May 2016. The samples were

\begin{tabular}{|l|}
\hline Ke e y w or d s \\
Hepatitis B Virus, \\
Serological and \\
Molecular \\
Diagnosis. \\
\hline Article Info \\
\hline $\begin{array}{l}\text { Accepted: } \\
\text { 15 February 2017 } \\
\text { Available Online: } \\
\text { 10 March 2017 }\end{array}$ \\
\hline \hline
\end{tabular}
analyzed by ELISA and Real Time - PCR techniques for detecting the prevalence of HBV in patients. The obtained results showed that a total of $50 \mathrm{HBs} \mathrm{Ag}$ serum samples collected from HBV infected patients and 25 control were tested by qualitative real-time PCR technique as confirmatory, regarding to patients groups (treated and untreated) the results of direct amplification showed statistically significant importance $(\mathrm{P}<0.05)$ in comparison with the serological marker. Results showed $96 \%$ positive, $4 \%$ negative of treated and untreated groups by quantitative RT-PCR and $88 \%$ positive and $12 \%$ negative by qualitative RT-PCR. Sixty sera samples were collected from treated, untreated and control groups tested by quantitative real - time PCR HBV DNA. The results pointed out that 25 samples for each treated, untreated, and control groups; samples results were found 25 untreated $(100 \%)$ and treated samples $(85 \%)$ positive; and treated samples (15\%) negative and 25 control samples $(100 \%)$ negative. The results were identical between qualitative RT-PCR and quantitative RT-PCR tests performed. ELISA Test System is a qualitative enzyme-linked immunosorbent assay (ELISA) for the detection of HBs Ag human serum or plasma that appears in virtually all individuals infected with $\mathrm{HBV}$ and is an accurate serological marker of current and past infection. ELISA procedures provide a means for routinely detecting antibodies to specific antigens. However, PCR amplification of virus DNA is potentially a more sensitive assay.

\section{Introduction}

Hepatitis B virus (HBV) has a small DNA genome that is partially double-stranded (Alvarado Mora et al., 2010). HBV contains numerous antigenic components, including HBs Ag, hepatitis B core antigen ( $\mathrm{HBc}$ Ag), and hepatitis B e antigen (HBe Ag). Humans are the only known host for HBV, although some nonhuman primates have been infected in laboratory conditions. HBV is relatively resilient and, in some instances, has been shown to remain infectious on environmental surfaces for more than 7 days at room temperature (Abdou et al., 2010). An estimated 2 billion persons worldwide have been infected with $\mathrm{HBV}$, and more than 350 million persons have chronic, lifelong 
infections. HBV infection is an established cause of acute and chronic hepatitis and cirrhosis. It is the cause of up to $50 \%$ of hepatocellular carcinomas (HCC) (Debika and Chloe, 2010).

Several well-defined antigen-antibody systems are associated with HBV infection. HBs Ag, formerly called Australia antigen or hepatitis-associated antigen, is an antigenic determinant found on the surface of the virus. It also makes up sub viral 22-nm spherical and tubular particles. $\mathrm{HBs} \mathrm{Ag}$ can be identified in serum 30 to 60 days after exposure to $\mathrm{HBV}$ and persists for variable periods. HBs Ag is not infectious (Ghosh et al., 2015). Recently, the polymerase chain reaction (PCR) was used for detecting $\mathrm{HBV}$ DNA in liver and serum, HBV PCR can be used for the identification of low level HBV viremia in HBsAg positive subjects with active liver disease without HBV-DNA positivity in standard hybridization technique. It is also useful for the appraisal of $\mathrm{HBV}$ infection in liver transplantation, evaluation of antiviral treatment and for the diagnosis of HBs Ag in acute or chronic liver disease (Sharma et al., 2013).

To measure HBV DNA, also called "viral load," a laboratory measures how many HBV DNA units are found in a milliliter of blood. This result is written in international units per milliliter or IU/ml. High levels of HBV DNA, which can range from thousands up to millions, indicate a high rate of $\mathrm{HBV}$ replication. Low or undetectable levels-less than 2,000 IU/ml indicate an "inactive" infection (Mohammed et al., 2012). This technology utilizes three oligonucleotides in the PCR mix: a probe labeled with a fluorescent reporter dye and a quenching dye, as well as two primers. During amplification, the reporter dye is cleaved from the probe by the 5'-exonuclease activity of a DNA polymerase, allowing real-time measurement of the fluorescent light emissions from the reporter dye. In real-time PCR, there is a direct relationship between the starting template copy number and the number of cycles needed to measure a positive signal from the reporter dye (Welze et al., 2006). However, due to the great heterogeneity in HBV genomic sequences, designing primerprobe sets to detect and quantify all HBV genotypes by real-time PCR is challenging at best (Sharma et al., 2013).

The aim of this study is evaluation of HBs Ag marker among patients \& control group and to estimate the usefulness of Real Time PCR as a sensitive and specific tool to diagnose active hepatitis B in Iraqi Patients.

\section{Materials and Methods}

Fifty serum samples were collected from two groups (treated group was 16 males and 9 females; and untreated group was 14 males and 11 females) with age ranged between 23 - 68 years, of Hepatitis B patients in this study attended the Wasit central public health laboratory, Wasit province, Iraq; during the period from March to May 2018; and 25 healthy individuals (14 males and 11 females) in the current study were used. All serum samples were collected aseptically and stored at $-20{ }^{\circ} \mathrm{C}$ prior to testing. ELISA test used Biokit (Spain). For real-time PCR, the viral nucleic acid extraction by kit of DNA/RNA virus extraction that instant virus RNA/DNA kit (Germany). The Bosphore ${ }^{\circledR} \mathrm{HBV}-\mathrm{HCV}$ HIV Multiplex screening Kit v1, a ready to use kit of Hepatitis B virus DNA, Hepatitis C virus RNA or Human immunodeficiency virus RNA in human serum and plasma for real-time PCR was used.

\section{Results and Discussion}

Table 1 shows the distribution of Patients HBV according to age and gender. It was found that most of patients were located within $36-45$ years in treated and untreated 
groups with a percentage of $36 \%$ and $32 \%$ respectively, and it was found that the 56-68 years constitutes the least percentages of $12 \%$ and $16 \%$ in treated and untreated groups respectively. The results showed that males are more than females in treated and untreated groups. The present results were almost similar to those obtained by Al-Hilli and Ghadhban, (2000), Al - Azzawi (2007) and Al-Hammieary (2009) who mentioned that the high infection located within the third and fourth decades and the least infection located within the sixth decade.

\section{Estimation of HBV by ELISA test}

A total of 75 individuals were screened for the detection of $\mathrm{HBs} \mathrm{Ag}$ and divided into 4 groups according to age as shown in table 2 .

Also the results of this study coincide with several studies such as Claudio et al., 2008; Ahmed, 2013; and Abid, 2015, who found that most of positive HBs Ag were located in untreated group compared with treated and control groups. In HBV infections can be defined as the presence of HBsAg in the serum of an infected individual for at least six months or as the presence of HBsAg in a patient negative for immunoglobulin (Ig) $\mathrm{M}$ antibodies to the hepatitis $\mathrm{B}$ core antigen (HBcAg) (Shepard et al., 2006).

\section{Quantitative and Qualitative Real-Time PCR}

Tables 3 and 4 show of HBV by quantitative and qualitative real-time PCR in treated and untreated groups, a total 75 were tested by qualitative real-time PCR technique as confirmatory, regarding to patients groups, the results of direct amplification showed statistically significant importance $(5<0.05)$ in comparison with serological markers. Among the methods most commonly used for HBV DNA qualification assays based on real- time PCR technology.

Results (96\%) positive, (4\%) negative of treated and untreated groups by quantitative real-time PCR and (88\%) positive, (12\%) negative by qualitative real-time PCR the results of qualitative real-time PCR by using kit test must be positive or negative according ti the $\mathrm{Ct}$ value. The samples that cross the threshold in FAM channel are displayed with a positive $\mathrm{Ct}$ value, samples that do not cut the threshold are displayed a "No Ct" these samples are regarded as negative. All 25 samples in control groups gave negative (100\%). For these undetectable samples, the Cy5 data of the internal control should also be checked to avoid false negative results. Analytical sensitivity may be expressed as the limit of detection the smallest amount of the target marker that can be precisely detected. Realtime PCR assays have become more widely available and preferred in the initial evaluation of patients, and even, more importantly in the monitoring of both treated and untreated patients. The current lack of standardization between assays, which make it difficult to compare data from different laboratories will be resolved with the introduction of an HBV-DNA standard (Saldanha et al., 2001). In the future all results should be reported in $\mathrm{IU} / \mathrm{ml}$ (IU/ml equals approximately 5.6 genome $/ \mathrm{ml}$ ) (Keeffe et al., 2006). HBV treatment monitoring is based on HBV DNA quantifications and ALT determinations every 3 to 6 months, whatever the $\mathrm{HBe}$ serostatus and antiviral treatment (Pawlotsky et al., 2008).

The amount of viral genome has been obtained by detecting a visible increase in fluorescence as the cycles progressing during the reaction (Growth Curve) as illustrated in figure 1. 
Table.1 The distribution of patient's HBV according to the age and gender

\begin{tabular}{|c|c|c|c|c|c|c|c|c|c|c|c|c|}
\hline \multirow{3}{*}{$\begin{array}{l}\text { Age } \\
\text { Years }\end{array}$} & \multicolumn{4}{|c|}{ Treated group } & \multicolumn{4}{|c|}{ Untreated group } & \multicolumn{4}{|c|}{ Untreated group } \\
\hline & \multicolumn{4}{|c|}{ Gender } & \multicolumn{4}{|c|}{ Gender } & \multicolumn{4}{|c|}{ Gender } \\
\hline & $M$ & $F$ & $\mathrm{~T}$ & $\%$ & $M$ & $F$ & $\mathrm{~T}$ & $\%$ & $M$ & $\mathrm{~F}$ & $\mathrm{~T}$ & $\%$ \\
\hline $23-35$ & 4 & 3 & 7 & 28 & 4 & 3 & 7 & 28 & 4 & 4 & 8 & 32 \\
\hline $36-45$ & 6 & 3 & 9 & 36 & 5 & 3 & 8 & 32 & 5 & 4 & 9 & 36 \\
\hline $46-55$ & 4 & 2 & 6 & 24 & 3 & 3 & 6 & 24 & 2 & 2 & 4 & 16 \\
\hline $56-68$ & 2 & 1 & 3 & 12 & 3 & 1 & 4 & 16 & 2 & 2 & 4 & 16 \\
\hline $\begin{array}{c}\text { Total } \\
\%\end{array}$ & $\begin{array}{l}16 \\
64\end{array}$ & $\begin{array}{c}9 \\
36\end{array}$ & 25 & 100 & $\begin{array}{l}15 \\
60\end{array}$ & $\begin{array}{l}10 \\
40\end{array}$ & 25 & 100 & $\begin{array}{l}13 \\
52\end{array}$ & $\begin{array}{l}12 \\
48\end{array}$ & 25 & 100 \\
\hline
\end{tabular}

Table.2 Seroprevalence of HBs Ag markers among treated, untreated and control groups

\begin{tabular}{|c||c|c|c||c|c|c||c|c|c|}
\hline \multirow{2}{*}{$\begin{array}{c}\text { Age } \\
\text { Years }\end{array}$} & \multicolumn{3}{|c||}{ Treated group } & \multicolumn{3}{c||}{ Untreated group } & \multicolumn{3}{c|}{ Control group } \\
\cline { 2 - 10 } & \multicolumn{3}{|c|}{ HBsAg } & \multicolumn{3}{c|}{ HBsAg } & \multicolumn{3}{c|}{ HBsAg } \\
\cline { 2 - 10 } & Total & $+\mathrm{Ve}$ & $\%$ & Total & $+\mathrm{Ve}$ & $\%$ & Total & $+\mathrm{Ve}$ & $\%$ \\
\hline \hline $23-35$ & 7 & 1 & 4 & 7 & 6 & 24 & 8 & 0 & 0 \\
\hline \hline $36-45$ & 9 & 3 & 12 & 8 & 7 & 28 & 9 & 0 & 0 \\
\hline \hline $46-55$ & 6 & 1 & 4 & 6 & 6 & 24 & 4 & 0 & 0 \\
\hline \hline $56-68$ & 3 & 0 & 0 & 4 & 4 & 16 & 4 & 0 & 0 \\
\hline \hline Total & 25 & 5 & 20 & 25 & 23 & 80 & 25 & 0 & 0 \\
\hline
\end{tabular}

Table.3 Estimation of HBV by quantitative and qualitative real-time PCR (Treated group)

\begin{tabular}{|c|c|c|c|c|c|}
\hline \multirow{2}{*}{$\begin{array}{c}\text { Age } \\
\text { Years }\end{array}$} & \multirow{2}{*}{ Gender } & \multicolumn{2}{|c|}{ Quantitative } & \multicolumn{2}{|c|}{ Qualitative } \\
\hline & & $+\mathrm{Ve}$ & $-\mathrm{Ve}$ & $+\mathrm{Ve}$ & $-\mathrm{Ve}$ \\
\hline \multirow{2}{*}{$23-35$} & $\mathrm{M}$ & 4 & 0 & 4 & 0 \\
\hline & $\mathrm{F}$ & 3 & 0 & 3 & 0 \\
\hline \multirow{2}{*}{$36-45$} & $\mathrm{M}$ & 6 & 0 & 6 & 0 \\
\hline & $\mathrm{F}$ & 3 & 0 & 3 & 0 \\
\hline \multirow{2}{*}{$46-55$} & $\mathrm{M}$ & 4 & 0 & 3 & 1 \\
\hline & $\mathrm{F}$ & 2 & 1 & 1 & 1 \\
\hline \multirow{2}{*}{$56-68$} & $\mathrm{M}$ & 2 & 0 & 2 & 0 \\
\hline & $\mathrm{F}$ & 1 & 0 & 0 & 1 \\
\hline \multirow{2}{*}{ Subtotal } & $\mathrm{M}$ & 16 & 0 & 15 & 1 \\
\hline & $\mathrm{F}$ & 8 & 1 & 7 & 2 \\
\hline $\begin{array}{c}\text { Total } \\
\%\end{array}$ & & $\begin{array}{c}24 \\
(96 \%)\end{array}$ & $\begin{array}{c}1 \\
(4 \%)\end{array}$ & $\begin{array}{c}22 \\
(88 \%)\end{array}$ & $\begin{array}{c}3 \\
(12 \%)\end{array}$ \\
\hline
\end{tabular}


Table.4 Estimation of HBV by quantitative and qualitative real-time PCR (Untreated group)

\begin{tabular}{|c|c|c|c|c|c|}
\hline \multirow{2}{*}{$\begin{array}{c}\text { Age } \\
\text { Years }\end{array}$} & \multirow{2}{*}{ Gender } & \multicolumn{2}{|c|}{ Quantitative } & \multicolumn{2}{|c|}{ Qualitative } \\
\hline & & $+\mathrm{Ve}$ & $-\mathrm{Ve}$ & $+\mathrm{Ve}$ & $-\mathrm{Ve}$ \\
\hline \multirow{2}{*}{$23-35$} & $\mathrm{M}$ & 4 & 0 & 4 & 0 \\
\hline & $\mathrm{F}$ & 3 & 0 & 3 & 0 \\
\hline \multirow{2}{*}{$36-45$} & $\mathrm{M}$ & 5 & 0 & 5 & 0 \\
\hline & $\mathrm{F}$ & 3 & 0 & 3 & 0 \\
\hline \multirow{2}{*}{$46-55$} & $\mathrm{M}$ & 2 & 1 & 2 & 1 \\
\hline & $\mathrm{F}$ & 3 & 0 & 2 & 1 \\
\hline \multirow{2}{*}{$56-68$} & $\mathrm{M}$ & 3 & 0 & 3 & 0 \\
\hline & $\mathrm{F}$ & 1 & 0 & 0 & 1 \\
\hline \multirow{2}{*}{ Subtotal } & $\mathrm{M}$ & 14 & 1 & 14 & 1 \\
\hline & $\mathrm{F}$ & 10 & 0 & 8 & 2 \\
\hline $\begin{array}{c}\text { Total } \\
\%\end{array}$ & & $\begin{array}{c}24 \\
(96 \%)\end{array}$ & $\begin{array}{c}1 \\
(4 \%)\end{array}$ & $\begin{array}{c}22 \\
(88 \%)\end{array}$ & $\begin{array}{c}3 \\
(12 \%)\end{array}$ \\
\hline
\end{tabular}

Fig.1 Showing the typical Real Time growth curve with its phases in which any fluorescence detected above a certain level threshold as the reaction cycles progress would be regarded as

(Positive) and those who fail to cross the threshold would be regarded as (Negative)

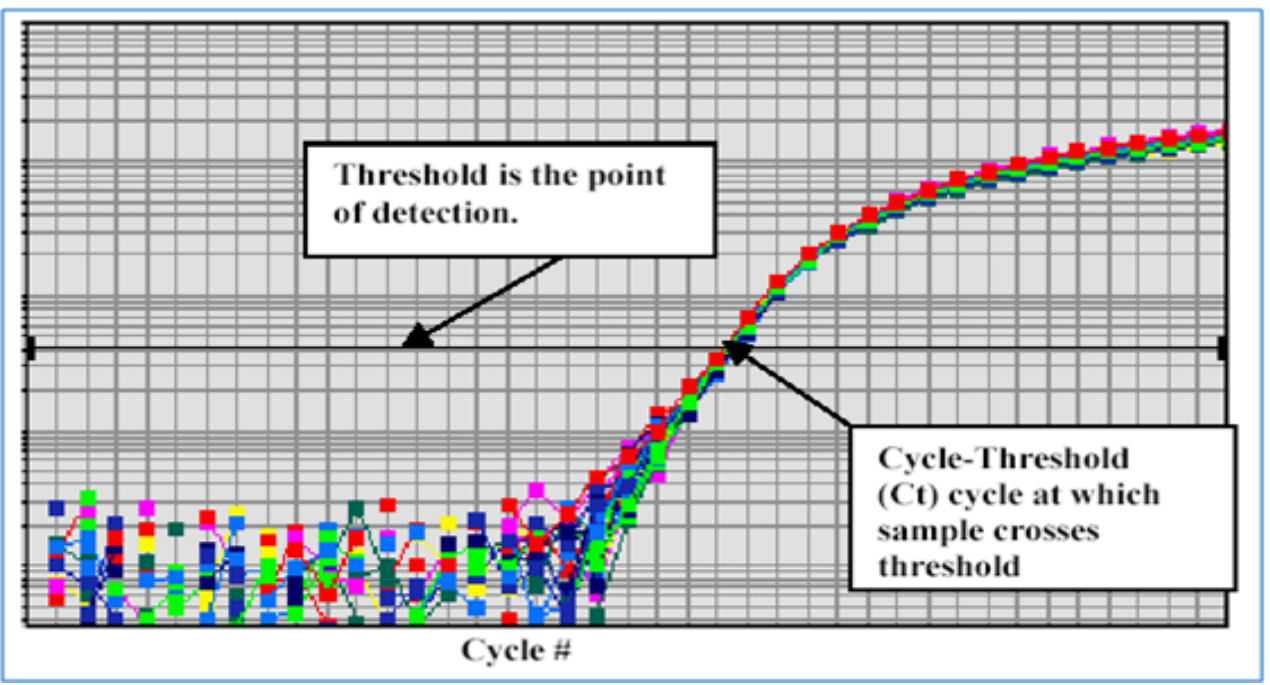

The cycle at which the fluorescence crosses a certain level (called Threshold) will be named as (Cycle Threshold) (Ct) which depends on the starting amount of the viral genome therefore, the software of the Real Time PCR utilizes that $\mathrm{Ct}$ (of standard samples) to create a standard curve to calculate precisely the viral load of unknown samples.

\section{Comparison between real-time and ELIZA} for detection of $\mathrm{HBV}$

The quantitative real time PCR assay for the detection of HBV-DNA is a highly sensitive method. Furthermore, the assay is less laborious than competitive PCR (Mudur, 2000). The entire process can be completed within a single day, including extraction of DNA. The real time 
PCR assay was performed by a single step, requiring a single tube, a single enzyme and a single set of primers with a target specific fluorogenic prob.

While in the same several epidemiologic studies of hepatitis B infection in South East Asia reveal a high incidence of the disease in China (5-18\%) and Taiwan (15-20\%) (Chen et al., 2000), Mudur, (2000) reported the highest incidence with a carrier rate of $23.35 \%$ among the Nicobarese tribe of the Nicobar islands which are situated in the Bay of Bengal, India.

The serological method of Enzyme-Linked Immunosorbent Assay (ELISA) gives the quantitative value in titres of antibodies detected in the serum. Levels of HBV-DNA in the blood serve as an important marker in monitoring the disease progression and treatment efficacy of chronic HBV infection. Several commercial assays are available for accurate measurement of HBV genomic DNA, but many of them are hampered by relatively low sensitivity and limited dynamic range. The high sensitivity, wide linear range, good reproducibility, and genotype inclusivity of this HBV real- time PCR assay, combined with a small sample volume requirement and low cost, make it particularly, well suited for application to large clinical and epidemiological studies. The quantitation of the HBV DNA level is very useful in monitoring the progression of the disease and the efficacy of treatment in HBV infection (Paraskevis et al., 2002). The present study showed an interesting and important data on comparing results for false negativity among groups with HBV.

This may be due to the high prevalence of HBV infection among groups. This suggests a higher specificity of RT-PCR than ELISA technique. Serological markers are indispensable in the diagnosis of $\mathrm{HBV}$ infection. $\mathrm{HBsAg}$, in spite of being a common diagnostic marker of $\mathrm{HBV}$ infection, does not provide information about active virus replication. The detection and quantification of hepatitis B virus (HBV)'s DNA play an important role in diagnosing and monitoring HBV infection as well as assessing therapeutic response. Despite the wide availability of good hepatitis B surface antigen (HBsAg)-based detection systems for hepatitis $B$ virus (HBV), there is evidence that transmission of HBV through blood and blood products occurs during the serological window period and more importantly during the later stages of infection due to occult hepatitis B infection as reported by Chu and Lok, (2002). Individuals negative for $\mathrm{HBsAg}$ but positive for HBV DNA in blood or tissues with or without the presence of HBV antibodies are categorized as occult HBV infection (Hu, 2002).

\section{References}

Abdou Chekaraou, M., Brichler, S., Mansour, W., Le Gal, F., Garba, A., Deny, P. and Gordien, E. 2010. A novel hepatitis B virus (HBV) subgenotype D (D8) strain, resulting from recombination between genotypes $\mathrm{D}$ and $\mathrm{E}$, is circulating in Niger along with HBV/E strains. J. Gen. Virol., 91: 1609 - 1620.

Abid, S. 2015. Detection of Anti-Helicobacter pylori antibodies and autoantibodies of celiac disease in patients with chronic Hepatitis B virus. M. Sc. Thesis. College of Science, Baghdad university, Iraq.

Ahmed, A. 2013. Determination of Hepatitis B virus genotypes among Iraqi chronic Hepatitis B patients and inactive HBV carriers. Ph. D. thesis. Institute of genetic engineering and biotechnology for postgraduate studies, Baghdad university, Iraq.

Al-Azzawi, R.H.M. 2007. A comparative study of some immunological aspects in vivo and in vitro in patients with chronic hepatitis $\mathrm{B}$ and $\mathrm{C}$ virus (pre- and posttreatment. Ph. D. thesis, college of Science, Baghdad university, Iraq.

Al-Hammieary, T.K.F. 2009. Seropidermiological and molecular study of hepatitis B virus in Al-Rusafa sector of Baghdad. M. Sc. Thesis, College of Science, Baghdad university, Iraq.

Al-Hilli, H.A.A. and Ghadhban, J.M. 2000. 
Prevalence of serological markers of HBsAg and HCV- antibodies among blood donors and certain risk groups. $J$. Fac. Med. Baghdad, 42(1): 45-49.

Chen, W.N., Oon, C.J. and Toh, I. 2000. Altered antigenicities of hepatitis B virus surface antigen carving mutations outside the common's determinant. Am. J. Gastroenterol., 95: 1098-1099.

Chu, C.J. and Lok, A.S. 2002. Clinical utility in quantifying serum HBV DNA levels using PCR assays, J. Hepatol., 36: 549551.

Claudio, G., Elisa, O., Luigi, P., Renzo, B., Giacomo, C., Sara, V. and Gianluca, G. 2008. What is the role of serology for the study of chronic hepatitis B virus infection in the age of molecular biology? J. Med. Virolo., 80: 974-979.

Debika, B. and Chloe, L.T. 2010. Review of hepatitis B therapeutics. Clin. Infect. Dis., 51(10): 1201-1208.

Ghosh, M., Nandi, S., Dutta, S. and Malay, K.S. 2015. Detection of hepatitis B virus infection: A systematic review. World $J$. Hepatol., 7(23): 2482-2491.

$\mathrm{Hu}$, K.Q. 2002. Occult hepatitis B virus infection and its clinical implications. Viral Hepat., 9: 243-257.

Keeffe, E.B., Dieterich, D.T. and Han, S.H.B. 2006. A treatment algorithm for management of chronic hepatitis B virus infection in united state. An update. Clin. Gastroenterol. Hepatol., 4: 1-26.
Mohammed, G., Bassim, A. and Duraid, A. 2012. Real-Time PCR as a diagnostic tool for $\mathrm{HBV}$ infection in Iraq. The Iraqi postgraduate Med. J., 11(2).

Mudur, G. 2000. Research finds high hepatitis $\mathrm{B}$ rate in Indian island tribes. $\mathrm{Br}$. Med. J., 321: 404.

Paraskevis, D., Pult, C., Haid, A.N., Tassopoulos, M. and Raptopoulo, D. 2002. Development and assessment of a novel real-time PCR assay for quantitation of HBV DNA. J. Virol. Methods, 103: 201-212.

Pawlotsky, J.M. 2008. Virologic techniques for the diagnosis and monitoring of hepatitis B virus. Gastroenterol. Clin. Biol., 32(1 pt 2): S56-63.

Saldanha, J., Gerlich, W. and Leslie, N. 2001. A international of collaborative study to establish a WHO standard for hepatitis B virus DNA nucleic acid amplification techniques. Vox Sang, 80: 63-71.

Sharma, N., Ali, S., Nautiyal, S. C., Singh, V., Kumari, S. and Kumar, K. 2013. Hepatitis $B$ virus DNA quantification using TaqMan probe and its significance. Webmed. Central Mol. Biol., 4(3): 45-51.

Welze, T.M., Miley, W.J., Parks, T.L., Goedert, J.J., Whitby, D. and Ortiz-Conde, B.A. 2006. Real-Time PCR assay for detection and quantification of hepatitis $\mathrm{B}$ virus genotypes A to G. J. Clin. Microbiol., 44(9): 3325 - 3333.

\section{How to cite this article:}

Radii, I.J. and Saud, A.M. 2017. Comparative Assessment between Serological and Molecular Diagnosis for Patients Groups with Hepatitis B Virus. Int.J.Curr.Microbiol.App.Sci. 6(3): 742748. doi: https://doi.org/10.20546/ijcmas.2017.603.086 